\title{
Millennials between consumer ethnocentrism and attitudes towards local campaigns
}

\author{
Stere STAMULE \\ The Bucharest University of Economics Studies, Bucharest, Romania \\ stere.stamule@mk.ase.ro \\ Steluța TODEA
}

\begin{abstract}
This paper aims to measure the Romanian Millennials' ethnocentrism tendency, together with their attitude of consumption towards Romanian-made products. Millennials, known as the Generation $Y$, are the demographic cohort, following the Baby Boomers and the Generation X. There is no specific date in time when this cohort begins and ends, but researchers put the early 1980's as starting birth and, the mid-1990's to early 2000's as the ending birth year. Representing the youth and the young adult population, they are the principal source of worldwide influence in the world. Given the fast and massive changes of the society, in which the Generation $Y$ developed, there are numerous socio-psychological characteristics promoted by researchers, all of these being essential for buying and consumer status of Millennials. The data were gathered using a structured online questionnaire, filled in by 518 Romanian youngsters, representative for the Generation Y, aged between 15 to 34 years old. Ethnocentrism was measured using the consumer ethnocentric tendencies scale (CETSCALE) developed by Shrimp and Sharma (1987). The attitudinal statements were used to measure the consumption behavior towards locally made products. The data was analyzed with the SPSS 20.0 statistics software for Windows, using descriptive statistics, factor analysis and correlation. The research results underline the role of the government and industry in encouraging Romanians to buy local products.
\end{abstract}

Keywords: consumer ethnocentrism, buying attitudes, Millennials, Generation Y, Romanian-made products.

\section{Introduction}

In recent years, many researchers focused on the consumer ethnocentrism tendency (CET), although little has been done in Eastern European countries. There are many antecedents of CET mentioned and empirically tested in previous research works, grouped in four big categories of particularities by Shankarmahesh, (2016): psycho-social, economic, political and demographic. In the current study will refer mainly to the demographic ones, which showed conflicting results in empirical studies, measured by ethnocentrism among consumers with different demographic characteristics. CET related studies have looked at the demographics of the respondents as a separate set of antecedents. The advantage of using demographic antecedents lies in the opportunities of segmenting consumers according to their favorable and unfavorable disposition to buy foreign products.

The hypotheses of the research study are based on four such antecedents, namely: age, gender, education and income. Age. Cosmopolitism is the main influencer nowadays in the behavior of the youth. Even though the empirical evidence is mixed, there seems to be more empirical support for the argument that younger people will have lower CET scores than older people. Gender. An overwhelming body of evidence supports the proposition that women have higher ethnocentric scores than men. The underlying logic is that women are more conservative, conformist and collectivistic concerned about maintaining social 
harmony and positive feelings among group members. Education. But for a few exceptions, the findings on ethnocentrism among consumers with different education levels have almost been consistent pointing the more educated the people are, lower is the ethnocentrism. The underlying rationale is that more educated people are less likely to have ethnic prejudices and tend to be less conservative. Income. Many studies point that higher the income level, lower the ethnocentrism. Increased income levels provide more opportunities for travel and purchase of foreign products thus resulting in more cosmopolitan views. The economic and political environments play also very important roles in the consumers' preference for foreign products (Shankarmahesh, 2006).

On the other hand, this research article also summarizes the psycho-social characteristics and particularities specific to Generation Y, relevant for the concept of consumer ethnocentrism. These particularities are covered by the theories of personality, being mentioned and empirically tested in previous researches (Shankarmahesh, 2006). The most relevant definition of the personality for the field of the consumer's behavior was published in 1937 by Gordon Allport, an American psychologist, the first to study personality. Thus, it refers to the dynamic organization of the psycho-physical systems, that determines specific patterns of behavior, thinking (Carducci, 2009) and attitudes, characterizing the subject's relation with its environment (Golu, 2002).

The current study focuses on the validation/invalidation of the following research hypotheses:

Hypothesis no. 1. The first group of the Millennials (15-24 years old) are less ethnocentric than the others.

Hypothesis no. 2. Women, as part of Romanian Millennials have higher ethnocentric scores than the men.

Hypothesis no. 3. Higher the education level of the Romanian Millennials, lower the consumer ethnocentrism.

Hypothesis no. 4. Lower the income of the Romanian Millennials higher the consumer ethnocentrism.

\section{Literature review}

After the fall of the Berlin Wall and the decomposition of the Soviet Union, the liberalization of the markets and globalization started to be the main pillars in the development of most societies. These changes gave the international trade significant impulses. However, even if the tariff barriers have decreased considerably in the last decade, the non-tariff ones still persist. Jeannet and Hennesey (1995) consider that, barriers different from the formal ones against the international trade, should be classified as non-tariff barriers. Porter (1986:3, in Shankarmahesh, 2006, p.147) described these new changes as following: "While the postwar trend toward free trade has brought tariffs down and spawned regional trade pacts, the pressures and upheavals of the new international competition have taken their toll in a new wave of protectionism. Protectionism is not only on the rise but is taking more and more subtle forms. (p. 4)."

However, globalization also faces resistance behaviors. In this regard, Ger (1999, p. 65) stated: "The differentiating impact of globalization strengthens or reactivates national, ethnic, and communal identities" (Ger and Belk 1996b, p.284), representing an attempt to regain a sense of stability and identity. For the international marketers, it is important to understand how these reactions are manifested in the marketplaces. De Mooji (2004) 
considers that many consumption behaviors are based on longtime habits and that the harmonization between people's values or national feelings it's not supported by the globalization, while several other authors studied the consumption behavior of the clients within several sectors of the economy: retail industry (Stancu and Meghisan, 2012), telecommunications (Meghisan, 2015). On the other hand, global companies need to analyze the purchase decision process in their way to implement their strategies in several countries (Girboveanu et al., 2012, Miron et al., 2009), connected to the analysis of the local labor market tendency (Marcu et al., 2015) and financial stability of a country (Acatrinei et al., 2013).

There are four distinct generations of people, each of them having its distinct personal and generational particularities and concerns (Hobart and Sendek, 2016) that have a direct influence upon the consumer's buying behavior (Parment, 2011). There are also several ways of defining the generations, but sociologists refer to the term of cohort when they define and study a generation. The cohort refers to a group of people with the same particularities, born in a certain period of time, (Howe and Strauss, 2009) and living similar experiences and problems (Pînzaru et al., 2016). Moreover, they are the generation with the biggest orientation to consumption and purchasing power having a strong impact upon the economy (Janga, Kimb, \& Bonnc, 2011; Dima et al., 2016). Generation Y was born on the grounds of an increasing economy, the appearance and powerful influence of the mass media (Parment, 2011). But, the determining aspect in the description of Generation Y is the fact that they have grown and developed digitally. Millennials redefine the world's moral and social standards, Greenberg \& Weber (2008) sustaining that they are the most tolerant, open and diverse generation until present, that focuses on sustainability, peace and cultural diversity.

\section{Research methodology}

Taking into consideration the findings of previous studies as a point of departure, the present study aims to evaluate the level of CE of Romanian consumers and examine how the demographic variables influence it. Moreover, we measured the reliability and the consistency of the scale and used factorial analysis.

The questionnaire was divided into two parts. For first part, we used CETSCALE developed by Shimp and Sharma (1987) to measure the consumer ethnocentrism tendency. This scale consists of 17-point Likert scale described as one $=$ "strongly disagree" and $7=$ "strongly agree". CETSCALE scores can range from 17 to 119. The mean of ethnocentrism values indicates the intensity of ethnocentrism. The justification for the use of the scale is based on the reliability and validity confirmation by a large number of researchers (Durvasula et al, 1997; Sharma et al., 1995). As reported by Durvasula et al. (1997), CETSCALE high scores indicate high levels of ethnocentrism, while low scores indicate low ethnocentrism. This instrument is used to fulfil the first aim of the survey. In the second part, we asked the respondents for the demographic characteristics: age, gender, income and education. We wanted to see how these characteristics influence the CET.

Because the study was conducted in Romania, the questionnaire required translation into Romanian language. Back-translation was used to assure the accuracy of the translation. The final translated questionnaire was then pre-tested on a panel of ten 
Romanian Millennials. Members of this pre-test group were asked for any comments on the questionnaire, pertaining to ambiguity or awkwardness in the wording of the questions.

Quota sampling method is a non-probabilistic sampling method and it was defined by Saunders et al. (2012) as "a sampling method of gathering representative data from a group". The research sample was composed of 518 respondents, most of them women (54.6\%). The sample age is 15 to 34 years old, most of them with the following level of education: undergraduate studies (32.8\%), master's degree (32.6\%) and high-school (26\%). The monthly average income in the family is: $\leq 1000$ RON (10.5\%), $1001-2000$ RON (22.1\%), 2001 - 3000 RON (28\%), 3001 - 4000 RON (13.2\%), over 4000 RON $(19.2 \%)$. The nonresponses for income represent a number of 36 respondents.

\section{Results}

The following step of our research is to validate/invalidate the formulated hypotheses.

Hypothesis no. 1. The first group of the Millennials (15-24 years old) are less ethnocentric than the others.

\begin{tabular}{|l|c|c|c|c|c|}
\hline \multicolumn{6}{|c|}{ Table 1. Romanian Consumer Ethnocentrism by Age Analysis } \\
\hline Descriptive Statistics & N & Min & Max & Mean & $\begin{array}{c}\text { Std. } \\
\text { Deviation }\end{array}$ \\
\hline a. 15-24 years & 167 & 17 & 119 & 67.79 & 25.44 \\
\hline a. 25-34 years & 352 & 17 & 119 & 69.62 & 24.93 \\
\hline
\end{tabular}

Source: Authors' analysis, data processed with SPSS v. 20 for Windows.

Hypothesis no. 1 is verified. The younger Millennials (67.79) are less ethnocentric than the older ones (69.62) (Table 1).

Hypothesis no. 2. Women, as part of Romanian Millennials have higher ethnocentric scores than the men.

\begin{tabular}{|l|c|c|c|c|c|}
\hline \multicolumn{6}{|c|}{ Table 2. Romanian Consumer Ethnocentrism by Gender Analysis } \\
\hline Descriptive Statistics & N & Min & Max & Mean & $\begin{array}{c}\text { Std. } \\
\text { Deviation }\end{array}$ \\
\hline a. Gender = feminine & 283 & 17 & 119 & 68.16 & 24.32 \\
\hline a. Gender = masculine & 235 & 17 & 119 & 70.08 & 25.99 \\
\hline
\end{tabular}

Source: Authors' analysis, data processed with SPSS v. 20 for Windows.

Hypothesis no. 2 is not verified. The women (68.16) are less ethnocentric than men (70.08). This result is similar with the results of other researches from western more developed economies and is a little surprising, because in those societies the gender division played a much more important role (Grapard, 1997) (Table 2).

Hypothesis no. 3. Higher the education level of the Romanian Millennials, lower the consumer ethnocentrism.

Table 3. Romanian Consumer Ethnocentrism by Education Level Analysis

\begin{tabular}{|l|c|c|c|c|c|}
\hline Descriptive Statistics $^{\mathbf{a}}$ & $\mathrm{N}$ & $\mathrm{Min}$ & $\mathrm{Max}$ & Mean & Std. Deviation \\
\hline a. Last form of education = vocational school & 20 & 33 & 119 & 86.84 & 29.59 \\
\hline a. Last form of education = high-school studies & 135 & 17 & 119 & 74.53 & 24.19 \\
\hline a. Last form of education = post-secondary studies & 12 & 18 & 113 & 82.36 & 33.00 \\
\hline a. Last form of education = undergraduate studies & 170 & 20 & 119 & 66.93 & 22.92 \\
\hline a. Last form of education = Master's Degree & 169 & 17 & 119 & 64.32 & 24.64 \\
\hline a. Last form of education = Doctoral studies & 13 & 17 & 110 & 60.89 & 29.31 \\
\hline
\end{tabular}

Source: Authors' analysis, data processed with SPSS v. 20 for Windows. 3).

Hypothesis no. 3 is verified. The more educated people are less ethnocentric (Table 
Hypothesis no. 4. Lower the income of the Romanian Millennials higher the consumer ethnocentrism.

\begin{tabular}{|l|c|c|c|c|c|}
\hline Table 4. Romanian Consumer Ethnocentrism by Income Level Analysis \\
\hline Descriptive Statistics $^{\mathbf{a}}$ & $\mathrm{N}$ & Min & Max & Mean & Std. Deviation \\
\hline a. The average income in the family $=\leq 1000$ RON & 54 & 29 & 119 & 81.41 & 27.35 \\
\hline a. The average income in the family $=1001-2000$ RON & 114 & 17 & 119 & 72.15 & 23.23 \\
\hline a. The average income in the family $=2001-3000$ RON & 145 & 19 & 119 & 69.15 & 24.88 \\
\hline a. The average income in the family $=3001-4000$ RON & 68 & 18 & 108 & 68.03 & 23.40 \\
\hline a. The average income in the family $=$ over 4 000 RON & 99 & 17 & 117 & 57.53 & 23.00 \\
\hline
\end{tabular}

Source: Authors' analysis, data processed with SPSS v. 20 for Windows.

Hypothesis no. 4 is verified. The ethnocentrism of the consumers increases, when the income decreases (Table 4).

The higher the CESTSCALE mean is, the more ethnocentric the group is (Durvasula et al., 1997). CETSCALE scores were determined for the consumer group. The mean, the standard deviation, the minimum, the maximum, the skewness, and the kurtosis of the CETSCALE are 69.03, 25.09, 17, 119, 0.80, -0.684 (Table 5).

\begin{tabular}{|lr|}
\hline Table 5. Romanian Millennials Consumer Ethnocentrism Tendency \\
\hline $\mathrm{N} \quad$ Valid & 518 \\
Mean $\quad$ Missing & 0 \\
Std. Deviation & 69.03 \\
Skewness & 25.09 \\
Std. Error of Skewness & 0.08 \\
Kurtosis & 0.10 \\
Std. Error of Kurtosis & -0.68 \\
Minimum & 0.21 \\
Maximum & 17 \\
N of items & 119 \\
\hline
\end{tabular}

Source: Authors' analysis, data processed with SPSS v. 20 for Windows.

If we compare our CETSCALE (69.03) score to other countries in Eastern European part, we can see that the ethnocentrism score of Romanian Millennials is higher than the CETSCALE score obtained for Russian consumers (51.68), in the study of Russian consumers by Durvasula et al. (1997), but lower than scores reported for Poles (69.19) in the study conducted by Good and Huddleston (1995).

However, the difference in the demographics of the sample respondents and the time when the data was collected might prevent meaningful comparisons. As a culturally specific construct, ethnocentricity is contingent on environmental dynamics, which have been shown to be particularly volatile in transitional economies of CEE (Vida and Fairhurst, 1999). 


\begin{tabular}{|c|c|}
\hline Table & Code \\
\hline $\begin{array}{l}\text { Tendency scale 1_Romanian people should always buy Romanian products instead of } \\
\text { imports. }\end{array}$ & CET 1 \\
\hline Tendency scale 2_ Only those products that are unavailable in Romania should be imported. & CET 2 \\
\hline Tendency scale 3_Buy Romanian-made products. Keep Romania working. & CET 3 \\
\hline Tendency scale 4_ Romanian products, first, last and foremost. & CET 4 \\
\hline Tendency scale 5_ Purchasing foreign products is un-Romanian. & CET 5 \\
\hline $\begin{array}{l}\text { Tendency scale 6_It is not right to purchase foreign products, because it puts Romanians out } \\
\text { of jobs. }\end{array}$ & CET 6 \\
\hline Tendency scale 7_A real Romanian should always buy Romanian-made products. & CET 7 \\
\hline $\begin{array}{l}\text { Tendency scale } 8 \text { _ We should purchase products manufactured in Romania instead of letting } \\
\text { other countries get rich off us. }\end{array}$ & CET 8 \\
\hline Tendency scale 9_ It is always best to purchase Romanian products. & CET 9 \\
\hline $\begin{array}{l}\text { Tendency scale 10_ There should be very little trading or purchasing of goods from other } \\
\text { countries unless out of necessary. }\end{array}$ & CET 10 \\
\hline Tendency scale 11_ Romanians should not buy foreign products, because this hurts & CET 11 \\
\hline Romanian business and causes unemployment. & \\
\hline Tendency scale 12_ Curbs should be put on all imports. & CET 12 \\
\hline $\begin{array}{l}\text { Tendency scale 13_It may cost me in the long run but I prefer to support Romanian } \\
\text { products. }\end{array}$ & CET 13 \\
\hline Tendency scale 14_Foreigners should not be allowed to put their products on our markets. & CET 14 \\
\hline $\begin{array}{l}\text { Tendency scale 15_Foreign products should be taxed heavily to reduce their entry into } \\
\text { Romania. }\end{array}$ & CET 15 \\
\hline $\begin{array}{l}\text { Tendency scale } 16 \text { - We should buy from foreign countries only those products that we } \\
\text { cannot obtain within our own country. }\end{array}$ & CET 16 \\
\hline $\begin{array}{l}\text { Tendency scale 17_ Romanian consumers who purchase products in other countries are } \\
\text { responsible for putting their fellow Romanians out of work. }\end{array}$ & CET 17 \\
\hline
\end{tabular}

Source: Authors' analysis, data processed with SPSS v. 20 for Windows.

Factor analysis designates a set of multivariate statistical methods, whose main objective is to define the structure of correlations between a large numbers of variables by determining a set of common dimensions.

KMO Index (0.952) and Bartlett's Test of Sphericity allow the acceptance of factor analysis results (Table 7).

Table 7. MO and Bartlett's Test

\begin{tabular}{|c|c|c|}
\hline \multicolumn{2}{|c|}{ Kaiser-Meyer-Olkin Measure of Sampling Adequacy. } & 0.952 \\
\hline \multirow{3}{*}{ Bartlett's Test of Sphericity } & Approx. Chi-Square & 7290.314 \\
\hline & Df & 136 \\
\hline & Sig. & 0.000 \\
\hline
\end{tabular}

Source: Authors' analysis, data processed with SPSS v. 20 for Windows.

The conceptual meaning of CET was examined using exploratory factor analysis (SPSS v20). Results revealed one factor explaining 73.62\% of total variance (Table 8). 
Table 8. Total Variance Explained

\begin{tabular}{|c|c|c|c|c|c|c|c|c|c|}
\hline \multirow[t]{2}{*}{ Component } & \multicolumn{3}{|c|}{ Initial Eigenvalues } & \multicolumn{3}{|c|}{$\begin{array}{l}\text { Extraction Sums of Squared } \\
\text { Loadings }\end{array}$} & \multicolumn{3}{|c|}{$\begin{array}{l}\text { Rotation Sums of Squared } \\
\text { Loadings }\end{array}$} \\
\hline & Total & $\begin{array}{c}\% \text { of } \\
\text { Variance }\end{array}$ & $\begin{array}{c}\text { Cumulative } \\
\%\end{array}$ & Total & $\begin{array}{c}\% \text { of } \\
\text { Variance }\end{array}$ & $\begin{array}{c}\text { Cumulative } \\
\%\end{array}$ & Total & $\begin{array}{c}\% \text { of } \\
\text { Variance }\end{array}$ & $\begin{array}{c}\text { Cumulative } \\
\%\end{array}$ \\
\hline 1 & 10.078 & 59.280 & 59.280 & 10.078 & 59.280 & 59.280 & 4.226 & 24.858 & 24.858 \\
\hline 2 & 1.426 & 8.389 & 67.668 & 1.426 & 8.389 & 67.668 & 4.175 & 24.558 & 49.416 \\
\hline 3 & 1.013 & 5.958 & 73.627 & 1.013 & 5.958 & 73.627 & 4.116 & 24.211 & 73.627 \\
\hline 4 & 0.609 & 3.580 & 77.207 & & & & & & \\
\hline 5 & 0.491 & 2.887 & 80.094 & & & & & & \\
\hline 6 & 0.433 & 2.550 & 82.643 & & & & & & \\
\hline 7 & 0.402 & 2.365 & 85.009 & & & & & & \\
\hline 8 & 0.369 & 2.170 & 87.179 & & & & & & \\
\hline 9 & 0.338 & 1.989 & 89.168 & & & & & & \\
\hline 10 & 0.299 & 1.761 & 90.930 & & & & & & \\
\hline 11 & 0.276 & 1.624 & 92.554 & & & & & & \\
\hline 12 & 0.272 & 1.600 & 94.154 & & & & & & \\
\hline 13 & 0.250 & 1.469 & 95.623 & & & & & & \\
\hline 14 & 0.220 & 1.292 & 96.915 & & & & & & \\
\hline 15 & 0.192 & 1.128 & 98.043 & & & & & & \\
\hline 16 & 0.172 & 1.014 & 99.056 & & & & & & \\
\hline 17 & 0.160 & 0.944 & 100.000 & & & & & & \\
\hline
\end{tabular}

PICBE | 726

Source: Authors' analysis, data processed with SPSS v. 20 for Windows.

Table 9. Rotated Component Matrix ${ }^{a}$

\begin{tabular}{|l|c|c|c|}
\hline & \multicolumn{3}{|c|}{ Component } \\
\cline { 2 - 4 } & 1 & 2 & 3 \\
CET 4 & 0.832 & & \\
CET 3 & 0.789 & & \\
CET 13 & 0.729 & & \\
CET 1 & 0.711 & & \\
CET 9 & 0.711 & & \\
CET 6 & & 0.803 & \\
CET 5 & & 0.776 & \\
CET 17 & & 0.732 & \\
CET 7 & & 0.665 & \\
CET 14 & & 0.661 & \\
CET 11 & & 0.561 & \\
CET 16 & & & 0.803 \\
CET 2 & & & 0.754 \\
CET 12 & & & 0.737 \\
CET 10 & & & 0.706 \\
CET 15 & & & 0.605 \\
CET 8 & & & \\
\hline
\end{tabular}

Extraction Method: Principal Component Analysis.

Rotation Method: Varimax with Kaiser

Normalization.

a. Rotation converged in 6 iterations.

Source: Authors' analysis, data processed with SPSS v. 20 for Windows. 
The rotated factor matrix is presented in Table 9. The factor loadings in the table are presented in decreasing order of magnitude. Examining the rotated factor matrix, the set of attitudes loading on Factor 1 exhorts the perception that consumers are more astute towards locally made products. Therefore, Factor 1 is labeled as Nationalism. The set of attitudes loading on Factor II, on the other hand, seems to concentrate against everything which has to do with foreign. Based on the first three attitudes loadings and the last two attitudes factor loading, all of which suggest anti-foreign view of the consumer. Factor II is labelled Attitudes toward foreign-made products. Factor III has to do with protectionism measures. The attitudes exemplify, the view that consumers are mainly against imports and trade. Therefore, the final factor is labelled Restrictions-mentality. The descriptors of the sets of attitudes for the students were Nationalism, Attitudes toward foreign-made products and Restrictions-mentality.

Cronbach's alpha of 0.957 was computed for the seventeen items in the CETSCALE, indicating a very good internal consistency for the scale. This reliability of the scale is somewhat higher than the reliability estimates found in previous research with singlecountry samples (e.g. Good and Huddleston 1995; Shimp and Sharma 1987) (Table 10).

\section{Table 10. Reliability Statistics}

\begin{tabular}{|c|c|}
\hline Cronbach's Alpha & N of Items \\
\hline 0.957 & 17 \\
\hline
\end{tabular}

Source: Authors' analysis, data processed with SPSS v. 20 for Windows.

\section{Conclusions}

The current study indicates that Romanian Millennials consumers (15-24 years old), well, with higher income, leaving in the cities, are marginally ethnocentric.

The present study suffers the limitation of the sample dimension. Thus, the generalization of the findings for the entire population with various demographic profiles should be done with precaution.

Managerial implications. Understanding the ethnocentric tendencies among Romanian consumers can be helpful to domestic and international companies to correctly resource their expenditure strategies, formulate better marketing plans and strategies and policies. Considering the finding of significant differences among the gender, level of income and level of education of the consumers, these demographic variables may be used to segment the market.

The current research will be further developed, taking into consideration other factors that affect CET. It has been found that the level of CE varies among product categories. Sharma et al. (1995), indicated that the less important a product category the greater the ethnocentric tendencies and behavior exhibited by consumers. Also, Javalgi et al. (2005) found that the impact of CE in purchasing intention of a particular product is moderate when this product is perceived as absolutely necessary. Furthermore, Balabanis and Diamanopoulos (2004) argued that CE is a more consistent predictor of preferences for domestic products rather than for foreign products. In other words, CE leads to consumers preferring domestic products but not necessarily rejecting foreign ones. Shimp and Sharma (1987) also postulated that CE can explain why consumers prefer domestic over foreign products even when no obvious reason exists for this preference (e.g., when the domestic products are of better quality or cheaper). 


\section{References}

Acatrinei, M., Gorun, A. and Marcu, N. (2013). A DCC-GARCH model to estimate the risk to the capital market in Romania. Romanian Journal of Economic Forecasting, 1, 136148.

Balabanis, G., and Diamantopoulo,s A. (2004). Domestic country bias, country-of-origin effects, and consumer ethnocentrism: a multidimensional unfolding approach. J Acad Mark Sci 2004, 32(1), 80-95.

Carducci, B. (2009). The Psychology of Personality: Viewpoints, Research, and Applications. John Wiley \& Sons, Ltd., Publication.

De Mooij, M. (2004). Consumer Behavior and Culture: Consequences for Global Marketing and Advertising. Thousand Oaks, CA: Sage Publications.

DIMA, A.M., HADAD, S., \& CANTARAGIU, R. (2016). A conceptual analysis of businessuniversity knowledge transfers in the energy field. ENERGY, CLIMATE CHANGE AND SUSTAINABILITY, 201-207.

Durvasula, S., Andrews, C. J. and Netemeyer, R. G. (1997). A cross-cultural comparison of consumer ethnocentrism in the United States and Russia. Journal of International Consumer Marketing, 9(4), 73-84.

Ger, G. (1999). Localizing in the Global Village: Local Firms Competing in Global Markets. California Management Review, 41 (4), 64-83.

Ger, G. and Belk, R.W. (1996b). I'd Like to Buy the World a Coke: Consumptionscapes of the 'Less Affluent World. Journal of Consumer Policy, 19 (September), 271-304.

Girboveanu, S.-R., Craciun, L. and Meghisan, G.-M. (2012). The role of advertising in the purchase decision process. Analele Universitatii din Oradea, Stiinte Economice, TOM XVII, 897-902.

Golu, M. (2002). Bazele psihologiei generale. Bucureşti: Editura Universitară.

Good, L.K. and Huddleston, P. (1995). Ethnocentrism and the eastern European consumer: are feelings and intentions related? International Marketing Review 12, 35-48.

Grapard, U. (1997). Theoretical issues of gender in the transition from socialist regimes. Journal of Economic Issues, 31(3), 665-85.

Greenberg E. H. and Weber K. (2008). Generation We: How Millennial Youth Are Taking Over America and Changing Our World Forever. Emeryville: Pachatusan.

Hobart, J.W., and Sendek, H. (2016). Generaţia Mileniului 3 şi evoluţia leadershipului. Bucureşti : Editura BMI.

Howe, N. and Strauss, W., (2009). Millennials Rising: The Next Great Generation. New York: Knopf Doubleday Publishing Group.

Janga, J., Kimb, W. and Bonnc, M., (2011). Generation Y consumers' selection attributes and behavioral intentions concerning green restaurants. Published in the International Journal of Hospitality Management 30 (2011), 803- 811 Contents.

Javalgi, R.G., Khare, V.P., Gross, A.C. and Scherer, R.F. (2005). An application of the consumer ethnocentrism model to French consumers. International Business Review, Vol. 14, pp. 325-44.

Jeannet, J-P. and Hennesy, H.D. (1995). Global Marketing Strategies. 3rd ed., Houghton Mifflin, Boston, MA.

Marcu, N., Meghisan, G.-M. and Ciobanu, M.C. (2015). Research on Romanian Labour Market Dynamics. Rev. Chim., 66(9), 1540-1544. 
Meghisan, G.-M. (2015). Cultural influences on pre-pay mobile telecommunications services users. Management \& Marketing Journal, XIII (1), 1-7.

Miron, D., Dima, A. M., \& Vasilache, S. (2009). Indexes of Regional Economic Growth in PostAccession Romania. Romanian Journal of Economic Forecasting, 11(3), 138-152.

Parment, A. (2013). Generation Y vs. Baby Boomers: Shopping behavior, buyer involvement and implications for retailing. Journal of Retailing and Consumer Services 20 (2013) 189-199.

Pînzaru, F. E., Vatmanescu, M., Mitan A. and Săvulescu, R. (2016). Millennials at Work: Investigating the Specificity of Generation Y versus Other Generations. Article published in MANAGEMENT DYNAMICS IN THE KNOWLEDGE ECONOMY · January 2016.

Saunders, M., Lewis, P. and Thornhill, A. (2012). Research Methods for Business Students. 6th edition, Pearson Education Limited.

Sharma, S., Shimp, T.A. and Shin, J. (1995). Consumer ethnocentrism: a test of antecedents and moderators. Journal of Academy of Marketing Science.

Shimp, T. A. and Sharma, S. (1987). Consumer ethnocentrism validation of the CETSCALE construction and validation of the CETSCALE. Journal of Marketing Research, VVIV, (August), 280-289.

Stancu, I. and Meghisan, G.-M. (2012). Marketing study regarding the consumers behavior towards the Auchan hypermarkets from Romania. Procedia Economics and Finance, 3, 502-508.

Shankarmahesh, M. (2006). Consumer ethnocentrism: An integrative review of its antecedents and consequences. International Marketing Review, 23(2), 146-172.

Vida, I. and Fairhurst, A. (1999). Factors underlying the phenomenon of consumer ethnocentricity: evidence from four central European countries. The International Review of Retail, Distribution and Consumer Research, 9(4), 321-337. 